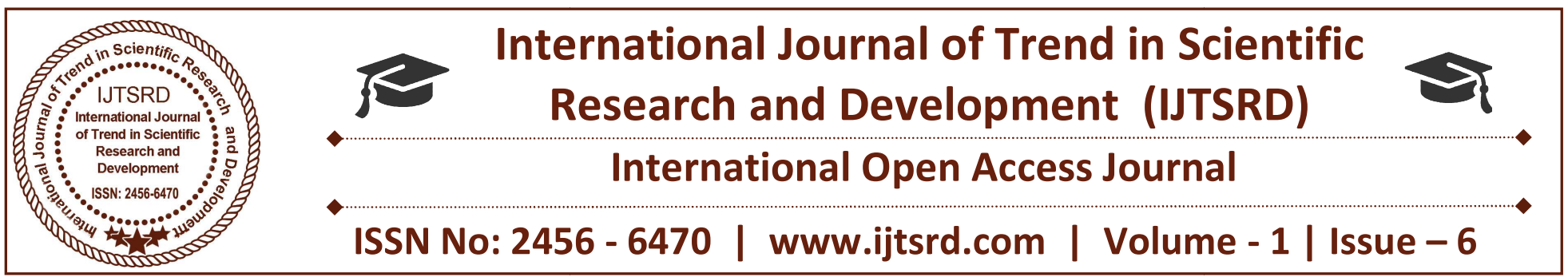

\title{
Potential and Performance of FDI Inflows in India
}

\author{
Vishruti Gupta \\ Ph.D Student, Delhi School of Economics, \\ University of Delhi
}

\author{
Pooja Sharma \\ Assistant Professor, Daulat Ram College, \\ University of Delhi
}

\author{
Vrinda Gupta \\ Independent Researcher
}

\section{ABSTRACT}

In the midst of era marked by globalisation, FDI is observed as a main driver of growth and development for all developing countries. India has been a recipient of substantial FDI inflows in recent years and has emerged as the fastest growing investment destination for foreign investors. This paper attempts to explore and highlight various factors that play critical role in determining the potential of FDI in India and then critically view the performance of FDI by analysing the trends in FDI over 1970-2016. The paper employs Principal Component Analysis (PCA) technique to construct an FDI potential index to assess the potentiality of India to draw in FDI. This index comprises of human capital, infrastructure, R\&D base and external trade and has been constructed for 19702016 to study the relation between FDI potential and FDI performance in India One key observation is a unique similarity in trends of all selected indicators for the above variables determining FDI potential index. Secondly, the FDI potential index is continuously rising in the given time period and exhibits a steep rise after 2010 showing that India is increasingly becoming the destination for all foreign investors in recent times. Lastly, the FDI potential index and FDI performance are highly significantly correlated.

Keywords: globalisation, Principal Component Analysis, human capital, R\&D base, infrastructure

\section{INTRODUCTION}

Foreign direct investment (FDI) is an investment made by the company or an individual in another country in the field related to either business operations, acquiring business assets is considered as FDI. In other words, 'Investment from one country into another usually by companies rather than governments that involves establishing operations or acquiring tangible assets including stakes in other businesses is considered as FDI ( Financial Times )'

According to another definition FDI is defined as 'mergers and acquisitions, building new facilities, reinvesting profits earned from overseas operations and intra company loans '. (Foreign Direct Investment, net inflows (BoP, current US\$)). There are various types of FDI, Horizontal FDI happens when the firms replicate their home country production activities at the same level of value chain stage in the host country through Investment in the host country. FDI is referred to as Platform FDI when investment takes place from a source country into a destination country with a purpose of exporting third country. While a vertical FDI happens if a firm through FDI moves upstream or downstream in the value chain when the firms are performing value addition activities stage by stage in a vertical direction in a host country (2012)

India has emerged as one of the fastest growing investment region for foreign investors in 2016. This rise in investment is mainly led by real estate investment and investment made in infrastructure sector from Canada ( KPMG report). All these 
developments in FDI has been a result of Indian government's policy reforms in creating a robust business environment and their efforts in improving ease of doing business through relaxation of FDI norms.

An increase in Government expenditure on infrastructure but at the same time controlled inflation are some of the predominant requirement for a substantial FDI inflows in an economy. These two factors also constitute macroeconomic stability. As a result a combination of these two variables would ensure not only a greater quantum of FDI but also macroeconomic stability.

From the growth perspective FDI boosts up the host country economy through absorptive capacities. It becomes a largest source of non-debt financial source for economic development in a developing country like India. There could be numerous ways in which the FDI can propagate or spill over economic growth through initiating competition, demonstrative and imitation effect, instigating skill development on account of human capital mobility. Another root of strengthening the economies could be empowering the small scale producers by injecting more capital which enhances their productivity and efficiency. (Aksoy, 2016) disaggregates FDI based on technological characteristics and investigates the kind of FDI that leads to output growth . Observing a sample of OECD countries for period between 1985- 2012, the study indicates that FDI inflows to ICTs ( Information and Communication Technologies ) and services sector plays no role in contributing to economic growth . Further, the paper concludes that only if the host country has sufficient level of human capital, financial resources and technological infrastructure will the ICT sector- based FDI foster economic growth

There is wide literature which links human capital to foreign inflows. (Jr, 1990) documents the importance of presence of human capital in countries for attracting foreign inflows. Similar discussions have been made in (Markusen, 1999) and (OECD, 2002)).

More educated and skilled workforce attracts more foreign investment to a country. If the work force is educated, it might be more capable of adapting to the technical advancements taking place in the country as a result of the "contagion effect" (Findlay, 1978). The MNCs may require incurring fewer costs on training the employees, if the workers are already skilled and capable. Therefore, it might be more cost effective for the foreign firms to invest in countries with educated and skilled human resource. (Easterlin, 1981) reports that the multinational corporations are more inclined to invest in countries where there is a sufficient supply of human capital because it reduces their transaction costs on training. Health is another important component of human capital. Healthy workers are physically and mentally more able than workers who are unhealthy or prone to disease. If the workers are healthy, they will be less likely to fall ill and hence reduce absenteeism. Also, healthy workers are in a better physical and mental state to work more productively. (Alsan, 2006) finds that foreign firms invest more in countries with healthy workforce.

Skill development and sources of finance are two critical aspects through which FDI inflow can directly enhance economic growth of the host country. Skill development, transfer of technology, technological know how, creating a R\&D base are some of the crucial channels for human capital formation which becomes a significant factor for economic growth. (Markusen, 1999) examined the causality running from direct investment to changes in country characteristics like wages skills etc. and also the opposite direction of causality from existing country characteristics to inward direct investment the paper observes that poorest countries attract a far smaller share of world direct investment than their share of income, small markets receive less investment per capita than the larger ones. The paper finally concludes that there exists a development trap for small, skilled labor scarce countries.

(Bushan Yasmin, 2003) analysed the volume and determinants of Foreign Direct Investment in developing countries taking a sample of 15 countries and applying fixed effect and random effect model concluded that urbanization, GDP per capita , standard of living, inflation, current account and wages affect FDI significantly in low income countries and the results vary owing to institutional and structural differences among countries. (Dic Lo. Fuhai Hong, 2016) concluded that Chinese economic development encompasses structuralism and radical political economy along with neoclassical economics. FDI in China promoted economic development by improving allocative efficiency but worsened productive efficiency resulting in overall effect on negative side

Moreover, there are several factors which contribute 
in attracting FDI in a particular country. Human capital base of a country which reflects not only the knowledge and skill base of individuals in the country but also the health status constitutes a significant factor for attracting FDI in the host country. Similarly the infrastructure base like roads, railways, well defined financial structure, availability of electricity etc are some the necessary ingredients for pulling the FDI in a country. At the same time Research and Development base along with status of external trade of a country provide significant contribution to building up of FDI potential

In the above mentioned context of evaluating the India's potential of attracting FDI, the paper would analyse the trends of each variable over the time period 1970-2017, using appropriate indicators which define the selected variables.

\section{METHODOLOGY}

In order to assess the ability of India or the potential of India to attract FDI, it is essential to compressively view all indicators that affect the capacity to attract FDI inflow . A composite index that can reflect all the parameters capturing the potential of India to attract FDI would be highly beneficial. The paper makes use of Principal Component Analysis (PCA) to evaluate and assess FDI potential of India.
The Principal Component Analysis reduces the dimensionality ie the number of indicators of the data set giving one composite index while retaining most of the original variability in the data. It has been often used in the literature to construct indices especially when the set of explanatory variables are highly correlated. The Principal Component Analysis can be computed using a variety of statistical packages. For the present study, PCA index has been constructed using STATA.

For the procedure, Eigen values above one are identified, explaining the maximum variation. After selecting the Eigen values, the components corresponding to the selected Eigen values are extracted from the Rotational matrix. The product of each selected Eigen value with the corresponding component is attained and summed up for each variable. Value of each variable is multiplied with the corresponding weight. A sum of all the cross products is obtained and divided with the grand total of all the weights to achieve one composite index.

The table below provides a detailed description of variables and the indicators selected to define FDI potential.

Table 1: Variable Description

\begin{tabular}{|c|c|c|c|c|c|}
\hline S. & Variables & \multicolumn{1}{|c|}{ Indicators } & Symbols & Units & Data Source \\
\hline 1 & Health & Life Expectancy at Birth & LF & Years & $\begin{array}{c}\text { World Development } \\
\text { Indicators, World } \\
\text { Bank Group }\end{array}$ \\
\hline 2 & Education & $\begin{array}{c}\text { Gross Enrolment Ratio at } \\
\text { tertiary Education }\end{array}$ & GER & $\%$ & $\begin{array}{c}\text { World Development } \\
\text { Indicators, World } \\
\text { Bank Group }\end{array}$ \\
\hline 3 & $\begin{array}{c}\text { R\&D base } \\
\text { (Intellectual } \\
\text { Property } \\
\text { rights) }\end{array}$ & $\begin{array}{c}\text { Number of Patent } \\
\text { Applications by Residents }\end{array}$ & PR & $\begin{array}{c}\text { Numerical } \\
\text { value }\end{array}$ & $\begin{array}{c}\text { World Development } \\
\text { Indicators, World } \\
\text { Bank Group }\end{array}$ \\
\hline 4 & $\begin{array}{c}\text { Infrastructure } \\
\text { Installed Generating } \\
\text { Capacity of Electricity in } \\
\text { Utilities and Non Utilities }\end{array}$ & CI & $\begin{array}{c}\text { Mega } \\
\text { Watts }\end{array}$ & MOSPI \\
\hline 5 & Exports & $\begin{array}{c}\text { Exports as a per } \\
\text { cent of GDP }\end{array}$ & EX & $\%$ & Reserve Bank of India \\
\hline
\end{tabular}

Author's Calculations 
The above table clearly categorises the variables used in determining FDI potential along with indicators used with their respective units and the data source.

\section{PATTERN OF FDI}

In the recent times, India has become the fastest growing investment region for most of the foreign investors in 2016. There has been an increase in the investment in real estate infrastructure, mainly from Canada (KPMG report). Major countries investing in India in the period between $2000-2017$ are given in the table below

Table 2: List of major countries investing in India between the period 2000-2017

\begin{tabular}{|l|l|l|}
\hline Country & FDI Inflows (US \$ Million) & FDI Inflows (\%) \\
\hline Mauritius & $114,930.60$ & 33.57 \\
\hline Singapore & $57,600.41$ & 16.82 \\
\hline Japan & $26,125.26$ & 7.63 \\
\hline United Kingdom & $24,731.43$ & 7.22 \\
\hline Netherlands & $21,265.96$ & 6.21 \\
\hline U.S.A & $20,982.97$ & 6.13 \\
\hline Germany & $10,496.29$ & 3.07 \\
\hline Cyprus & $9,278.57$ & 2.71 \\
\hline France & $5,823.63$ & 1.70 \\
\hline UAE & $4,765.10$ & 1.39 \\
\hline Switzerland & $3,901.27$ & 1.14 \\
\hline
\end{tabular}

Source: Department of Industrial Promotion and Policy

A substantial amount of FDI inflow in India has been from Mauritius and Singapore and service sector consisting of financial, banking, insurance, non-financial or business . outsourcing, R\&D, courier are some of the significant branches receiving a substantial amount of FDI. The table below clearly reveals the sources of FDI in India

Table 3: Major Sectors Receiving FDI between April 2000 and June 2017

\begin{tabular}{|l|l|l|}
\hline Sector & $\begin{array}{l}\text { FDI Inflows (US } \\
\text { Million) }\end{array}$ & FDI Inflows (\%) \\
\hline Service* & $61,359.43$ & 17.92 \\
\hline $\begin{array}{l}\text { Computer Software and } \\
\text { Hardware }\end{array}$ & $25,985.07$ & 7.59 \\
\hline $\begin{array}{l}\text { Construction Development** } \\
\text { Telecommunications }\end{array}$ & $24,543.84$ & 7.17 \\
\hline Automobile Industry & $24,033.74$ & 7.02 \\
\hline Drugs and Pharmaceuticals & $17,389.89$ & 5.08 \\
\hline
\end{tabular}


International Journal of Trend in Scientific Research and Development (IJTSRD) ISSN: 2456-6470

\begin{tabular}{|l|l|l|}
\hline Trading & $14,987.84$ & 4.37 \\
\hline $\begin{array}{l}\text { Chemicals other than } \\
\text { Fertilizers }\end{array}$ & $13,972.40$ & 4.08 \\
\hline Power & $11,765.82$ & 3.44 \\
\hline Hotel and Tourism & $10,477.29$ & 3.06 \\
\hline Metallurgical Industries & $10,394.68$ & 3.04 \\
\hline Construction & $10,256.48$ & 3.00 \\
\hline
\end{tabular}

*Includes Financial, Banking, Insurance, Non-Financial / Business, Outsourcing, R\&D, Courier, Tech. Testing Analysis

** Townships, housing, built-up infrastructure and construction-development projects Source: Department of Industrial Promotion and Policy

There are some of the significant policy initiatives made on behalf of government of India to foster an environment congenial for FDI investment, it was these policy reforms that instigated more and more FDI in India. Among the major reforms are Department of Industrial Policy and Promotion (DIPP) approved nine FDIs worth 780 million US dollars includes Amazon India. India and Japan joined hands for infrastructure development in North -East states. The Central Board of Direct Taxes (CBDT) has exempted employee stock options, FDI and transaction from long-term capital gain tax under Finance Act 2017. Further Government of India is likely to allow $100 \%$ FDI in cash and ATM management. Another significant development in context of policy reform is the scrapping of Foreign Investment Promotion Board (FIPB), this would enable all the foreign investors and companies requiring government approval to be cleared by ministries, improving ease of doing business to a greater extent. India has finally become the most attractive market for global partners, private investment in India are going to grow by $8.8 \%$. (IBEF (India Brand Foundation), 2017)

\section{FDI POTENTIAL INDEX}

FDI potential as the term indicates comprises of all the determinants that provide a sufficient base for foreign direct investment. There are several factors that play a critical role in empowering the capacity of an economy to draw FDI. These factors can be categorized as both socio- economic and institutional factors prevailing in the host countries. Human Capital constitutes a foundation for development of an economy. The investors who invest in a particular technology get attracted to skilled and better quality work - force who is well aware of latest technological know -how. Health status and education are two significant indicators of human capital. The study incorporates the Life Expectancy at Birth indicating health component of human capital and Gross Enrolment Ratio at Tertiary Education indicating the education component of human capital. This however also reflects the socio- economic status of an economy, a critical aspect to attract FDI.

Further, Infrastructure in form of roads, railways, availability of electricity are some of the essential parameters or prerequisites for foreign direct investment. Connectivity of all regions belonging to nations along with the financial lay out or structure play a critical role in attracting foreign firms to invest. Installed Generating Capacity of Electricity in Utilities and Non Utilities is taken as an indicator of infrastructure in India which substantially adds up to the FDI potential in India.

Apart from human capital and infrastructure, the technological innovation capability is highly essential for foreign investment. In the present world of rapidly changing technologies, in order to sustain one king of investment it is essential to innovate consistently. Number of patents filed serves as a good indicator to evaluate the R\&D base for India which in turn would attract technological investments from abroad.

Lastly, the external trade reflected by Exports as percentage of GDP would provide another effective characteristic for attracting FDI investors. A country that is well connected in the globalised world of today, would be able to attract significant investors sailing in the global market and finally benefit from them. 
A combination of all above variable described above would provide a substantial indicator that would evaluate the potential for India in context of FDI investments. As described in the diagram below, all the selected variables would define the potential of
FDI in India. Later, in turn, FDI potential would further play a crucial role in inducing FDI performance.

\section{Chart 1: Determinants of FDI Potential Index and linkages}

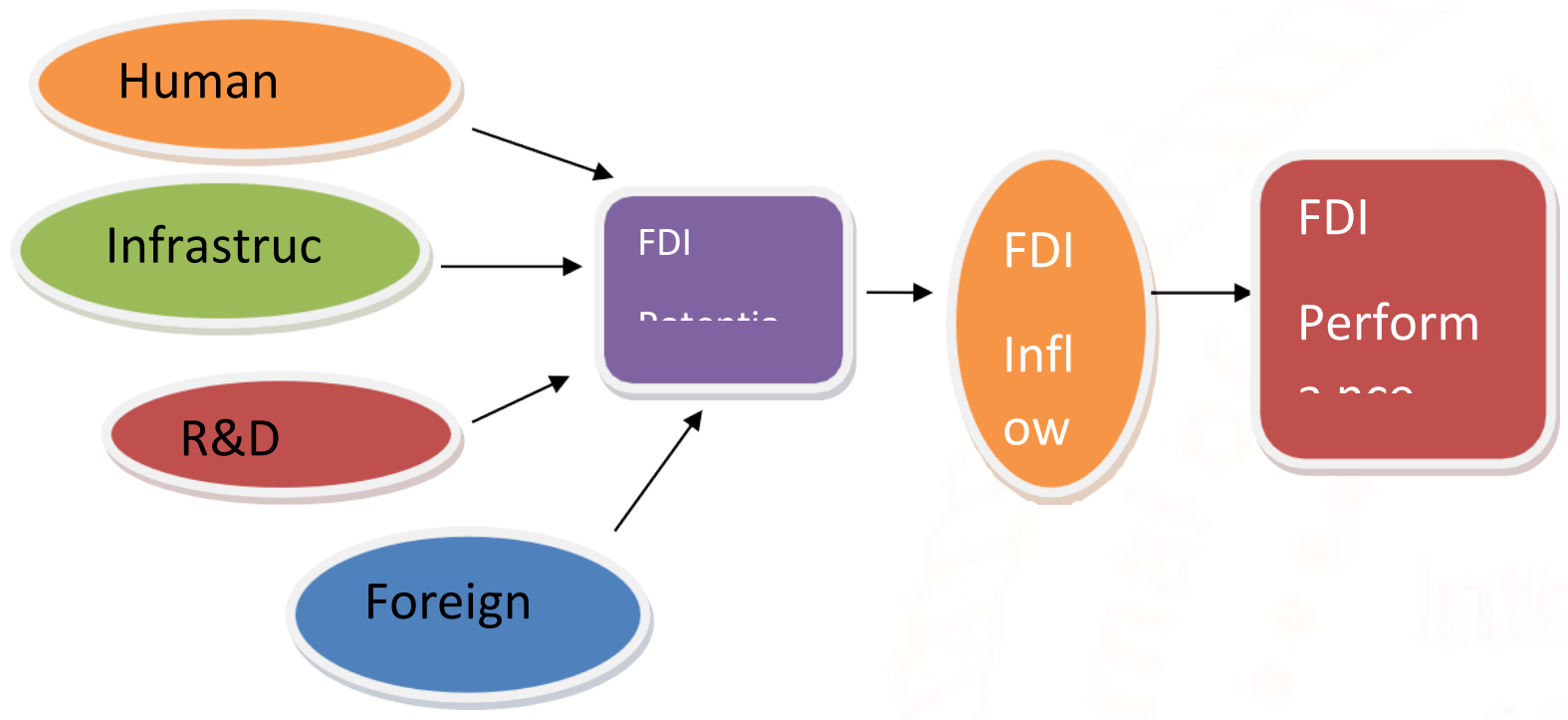

The above schematic diagram holistically explains the role of the selected variables namely human capital, infrastructure, R\&D base, Foreign Trade in determining the FDI potential. The FDI potential further regulates the FDI inflow which can be evaluated by FDI performance.

Since, in the present study, only the first component has eigen value above 1 as given below, we need not do the rotation and hence we take the component values from the Unrotational Matrix.

Principal Component Analysis- Correlation

Number of observations $=47$

Number of components $=5$

Trace $=5$

Rho $=1.00$

\begin{tabular}{|l|l|l|l|l|}
\hline Component & Eigenvalue & Difference & Proportion & Cumulative \\
\hline Comp1 & 4.5734 & 4.2479 & 0.9147 & 0.9147 \\
\hline Comp2 & 0.325502 & 0.243061 & 0.0651 & 0.9798 \\
\hline Comp3 & 0.082441 & 0.069472 & 0.0165 & 0.9963 \\
\hline Comp4 & 0.01297 & 0.007281 & 0.0026 & 0.9989 \\
\hline Comp5 & 0.005689 &. & 0.0011 & 1 \\
\hline
\end{tabular}

Principal Component Analysis- Eigenvectors 
International Journal of Trend in Scientific Research and Development (IJTSRD) ISSN: 2456-6470

\begin{tabular}{|l|c|c|c|c|c|c|}
\hline Variable & Comp1 & Comp2 & Comp3 & Comp4 & Comp5 & Unexplained \\
\hline GER & 0.4508 & -0.4422 & -0.0463 & -0.671 & 0.3858 & 0 \\
\hline LF & 0.43 & 0.6294 & -0.499 & 0.133 & 0.3892 & 0 \\
\hline EX & 1 & & & & & \\
\hline PR & 0.4421 & 0.4145 & 0.7786 & -0.1026 & -0.1265 & 0 \\
\hline CI & 0.4479 & -0.4783 & 0.1266 & 0.719 & 0.1941 & 0 \\
\hline
\end{tabular}

For Acronyms, refer to Table 1.

Using the above formulation for index construction gives a non-standardized index, the value of which can be positive or negative making it difficult to interpret. Therefore, a standardized index was created, the value of which can range between 0 and 1, using the formula below:

Standardized Index $=$

Non Standardized FDI Potential Indexi -

Min Non Standardized FDI Potential Index Max Non Standardized FDI Potential Index -

Min Non Standardized FDI Potential Index

\section{TRENDS AND DESCRIPTIVE STATISTICS OF VARIABLES}

The variables selected to explain and determine FDI index are human capital, external trade, $R \& D$ base and infrastructure, substantially indicated by Gross Enrolment ratio in tertiary education, life expectancy at birth, export as percentage of GDP, number of patents filed by residents, capacity installed.

Trends in these indicators would help in comprehending and analysing the role played by them in defining FDI potential of India for the period 19972017.

Graph1: Gross Enrolment ratio in Tertiary Education for 1970-2016

\section{Gross Enrolment Ratio in Tertiary Education}

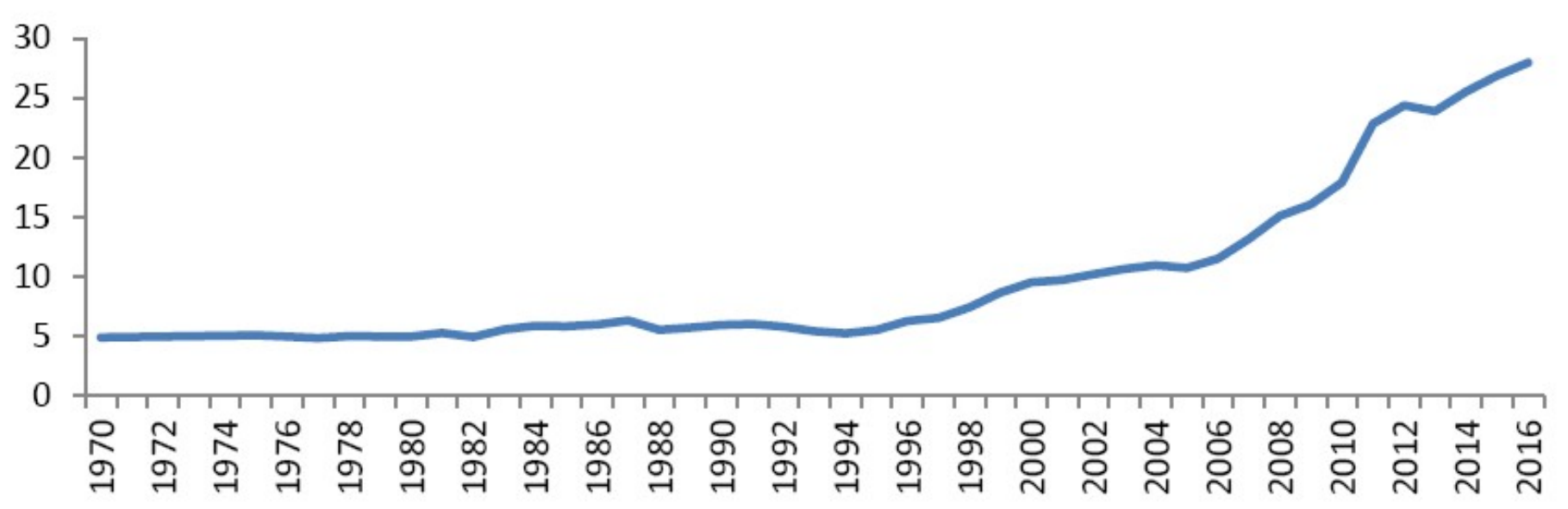

Author's calculations

Source: World Development Indicators, World Bank

Group 
Graph 2: Life Expectancy at Birth for 1970-2016

\section{Life Expectancy at Birth}

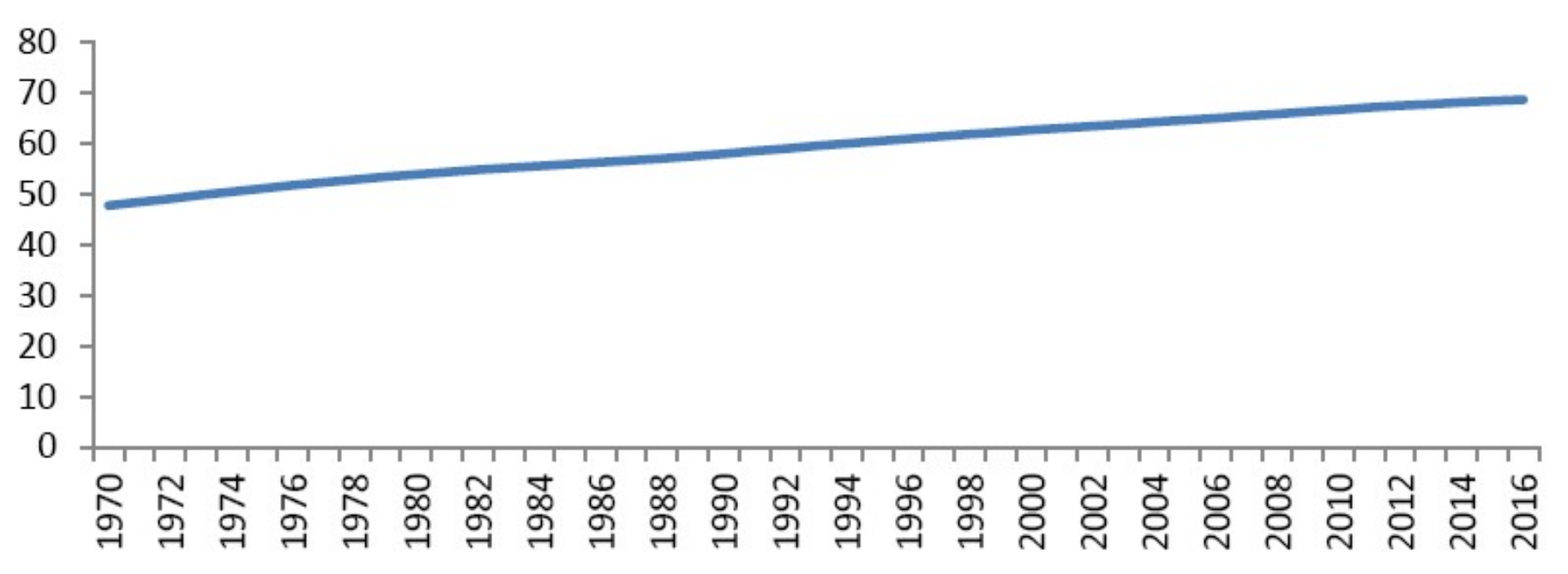

Author's calculations

Source: World Development Indicators, World Bank Group

Graph 3: Export as a per cent of GDP for 1970-2016

\section{Export as per cent of GDP}

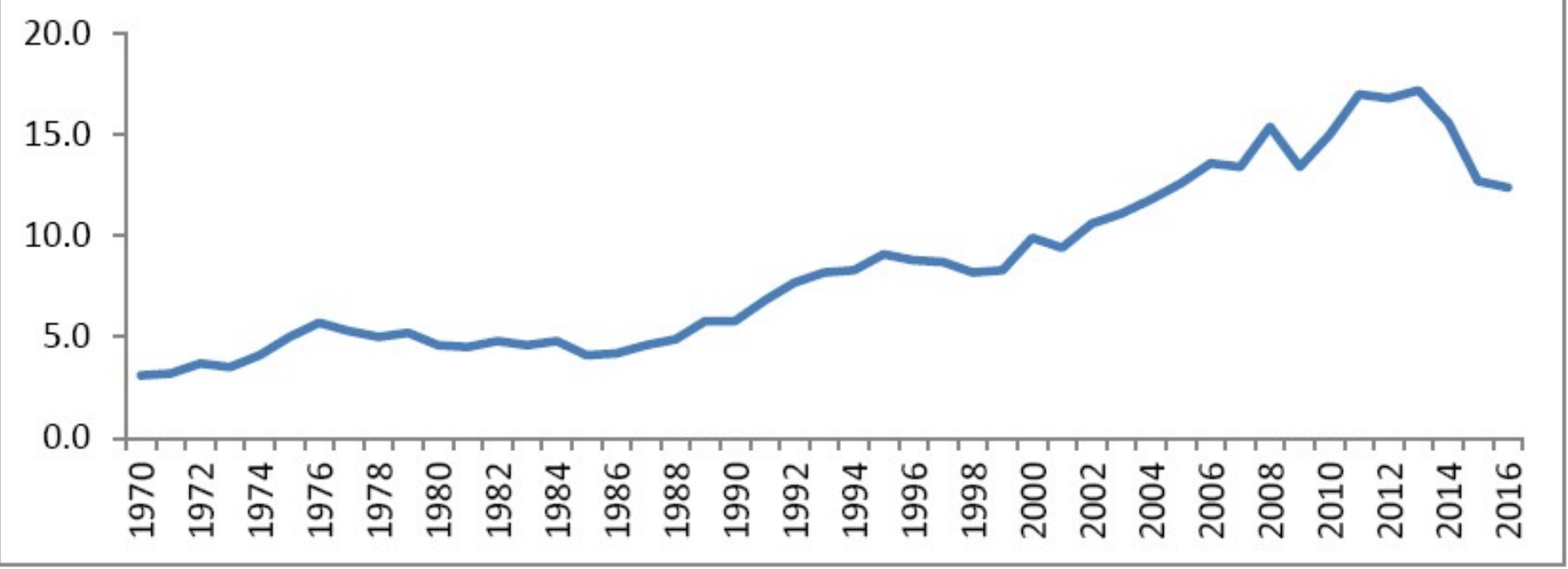

Author's calculations

Source: Reserve Bank of India 
Graph 4: Number of Patents filed by Residents for 1970-2016

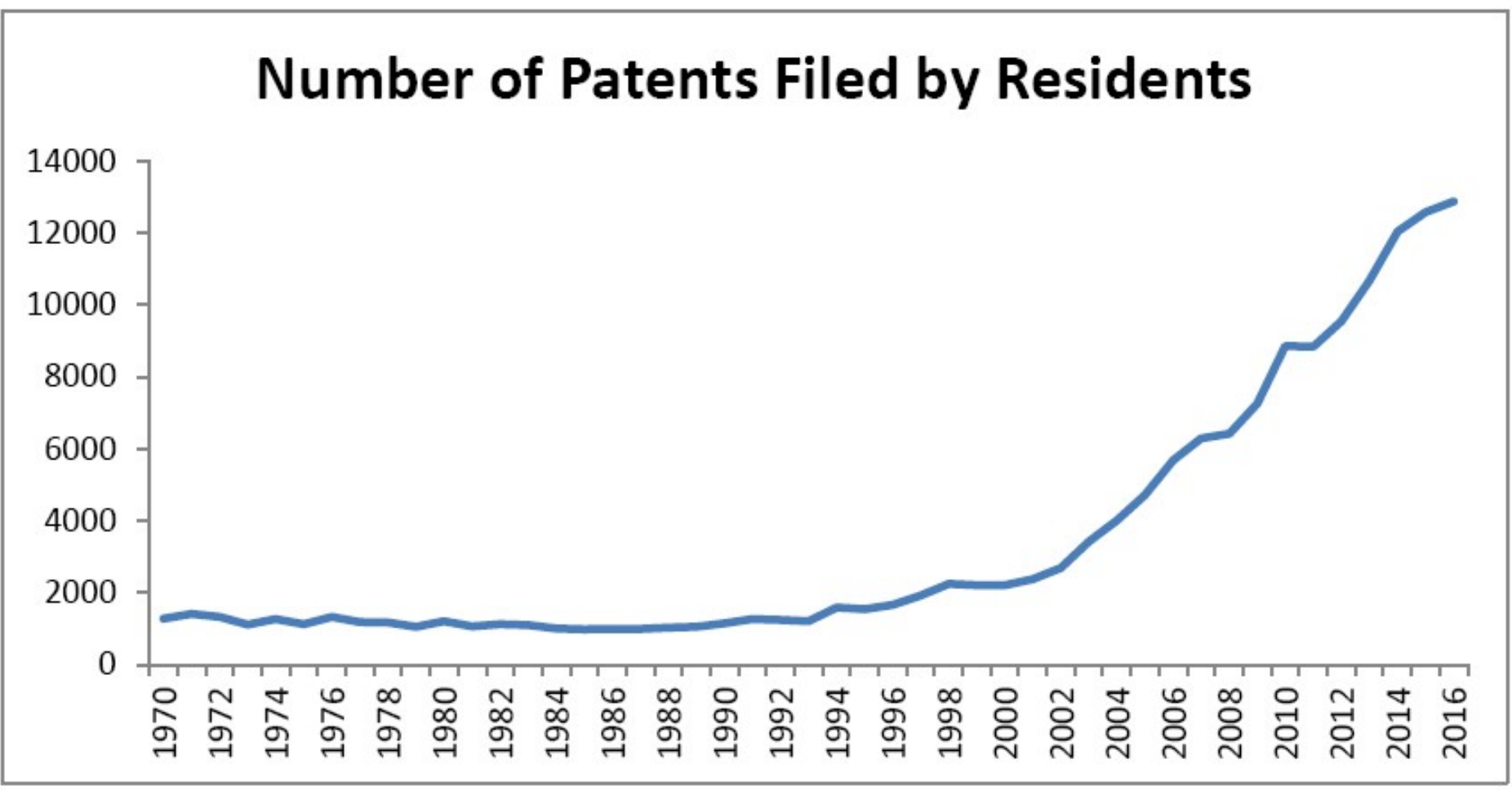

Author's calculations

Source: World Development Indicators, World Bank Group

Graph 5: Capacity Installed of electricity generation (MW) for 1970-2016

\section{Capacity Installed (MW)}

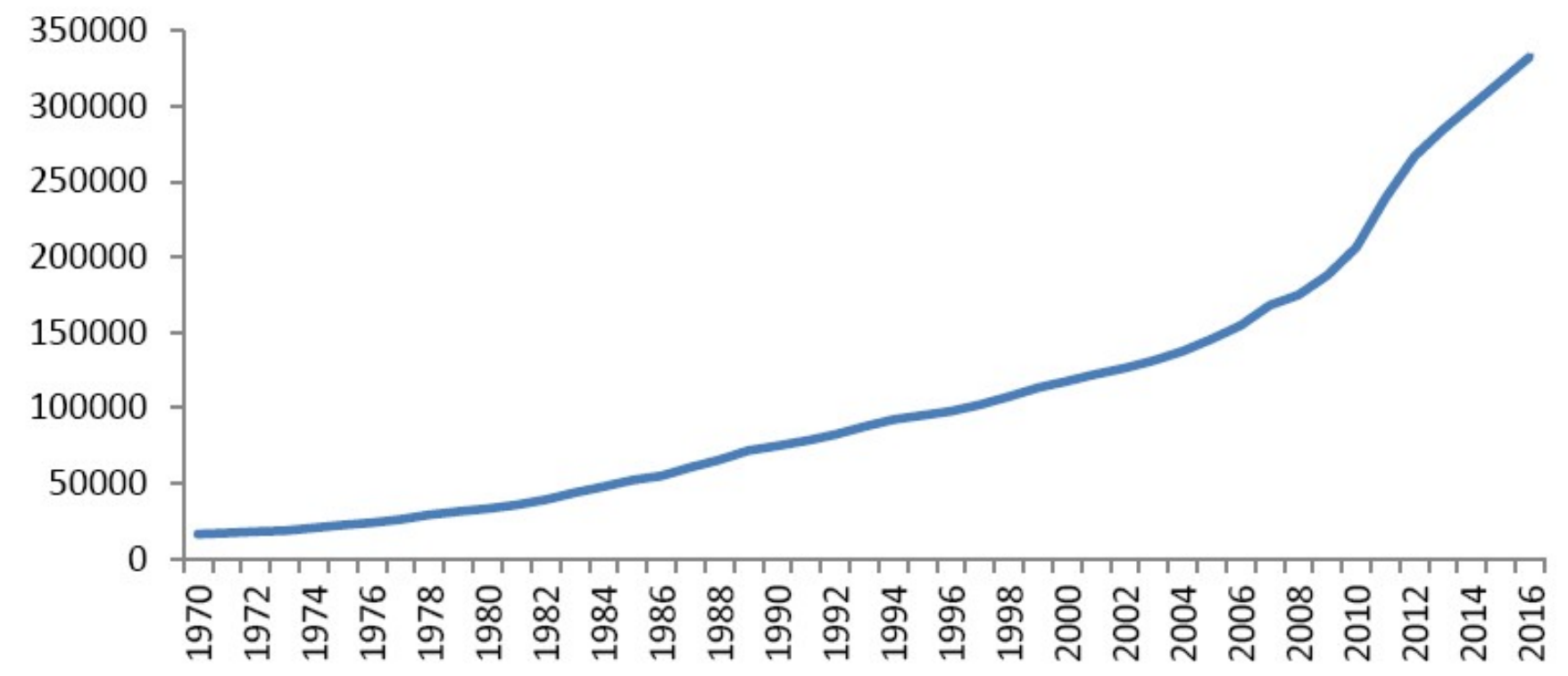

Author's calculations

Source: MOSPI 


\section{Graph 6: FDI Potential Index for1970-2016}

\section{FDI Potential Index}

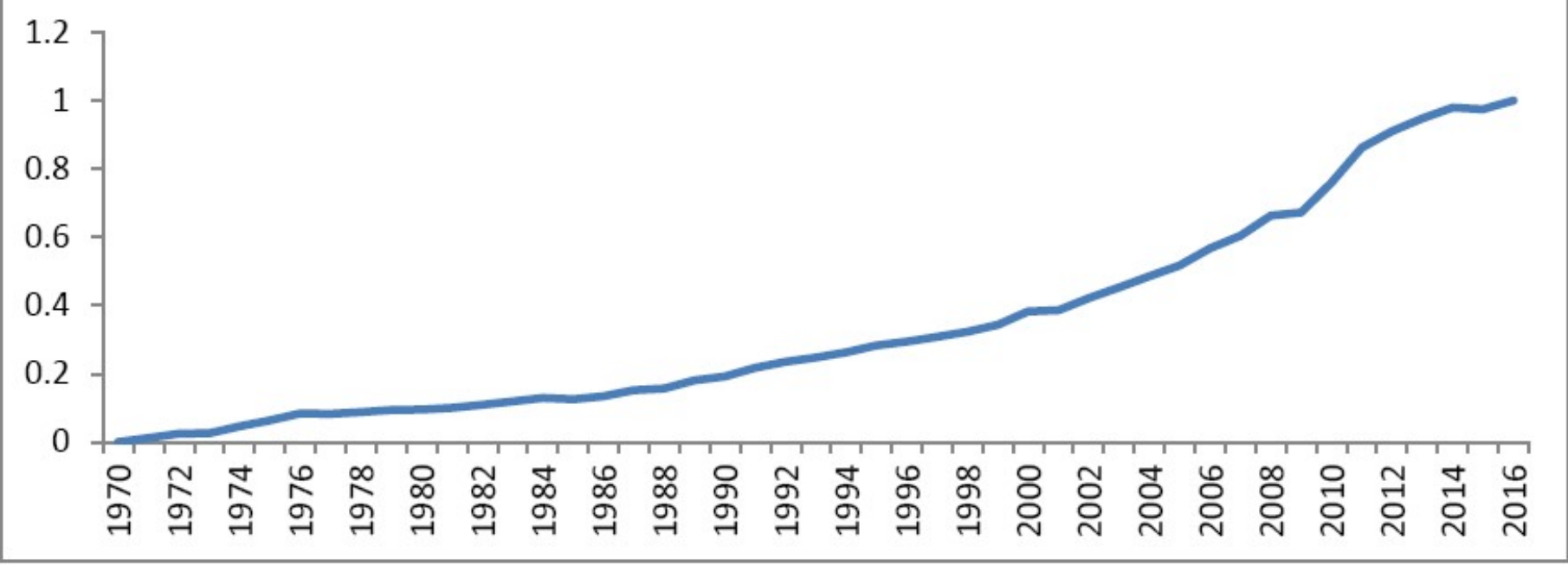

Author's Calculations

All the graphs above indicate that there is more or less similar trend in the indicators that they all start with low levels from 1970 onwards and slowly progressing towards higher and higher values after 2000 onwards. This clearly reveals to a great extent that each indicator affects FDI potential equally in a similar manner.

By observing the trends in FDI potential it is further reconfirmed that even the FDI potential reflects the similar trends as each of the selected indicator. This reinforces the fact that the selected variables and their corresponding indicators play a critical role in defining the FDI potential of India between the period 1997 2017.

\section{Descriptive Statistics of variables}

Table 4: Descriptive Statistics of variables

\begin{tabular}{|c|c|c|c|c|c|}
\hline Indicator & Obs & Mean & $\begin{array}{l}\text { Std. } \\
\text { Dev. }\end{array}$ & Min & Max \\
\hline $\begin{array}{l}\text { gross enrolment ratio in tertiary } \\
\text { education }\end{array}$ & 47 & $\begin{array}{l}9.71116 \\
5\end{array}$ & $\begin{array}{l}6.82255 \\
8\end{array}$ & 4.86899 & $\begin{array}{l}27.9637 \\
2\end{array}$ \\
\hline life expectancy at birth & 47 & $\begin{array}{l}59.1938 \\
3\end{array}$ & $\begin{array}{l}6.11008 \\
4\end{array}$ & $\begin{array}{l}47.7197 \\
6\end{array}$ & $\begin{array}{l}68.6092 \\
6\end{array}$ \\
\hline exports as per cent of GDP & 47 & $\begin{array}{l}8.47872 \\
3\end{array}$ & $\begin{array}{l}4.27937 \\
1\end{array}$ & 3.1 & 17.2 \\
\hline Number of patents & 47 & $\begin{array}{l}3391.04 \\
6\end{array}$ & $\begin{array}{l}3543.74 \\
2\end{array}$ & 982 & $\begin{array}{l}12878.3 \\
8\end{array}$ \\
\hline capacity installed (MW) & 47 & $\begin{array}{l}107928 . \\
7\end{array}$ & $\begin{array}{l}86822.2 \\
7\end{array}$ & 16271 & $\begin{array}{l}332952 \\
2\end{array}$ \\
\hline
\end{tabular}

Author's Calculations. 
The above results reveal that variance for capacity installed which is an indicator of infrastructure is highest followed by number of patents, an indicator of R\&D base. This suggests that there exists lot of variation from the mean for these two indicators.

\section{FDI PERFORMANCE : INDICATOR}

After undergoing a regressive task of examining the trends in FDI and later evaluating the determinants of FDI in India considering some of the crucial variables which substantially contribute in defining the FDI potential in India, it is essential to examine the performance of FDI in India for the selected time period 1990-2017. FDI as percentage of GDP is an appropriate indicator for FDI performance in India.

The following gives the trend in FDI performance in India between the period 1990- 2017 which clearly reveals that the FDI picks up around 1994 and reached its peak in 2008, the

year of global financial breakdown and after that starts reducing till 2012 and then again picks up in the recent years .

\section{Graph 7: FDI Performance: FDI as percentage of GDP for 1970-2016}

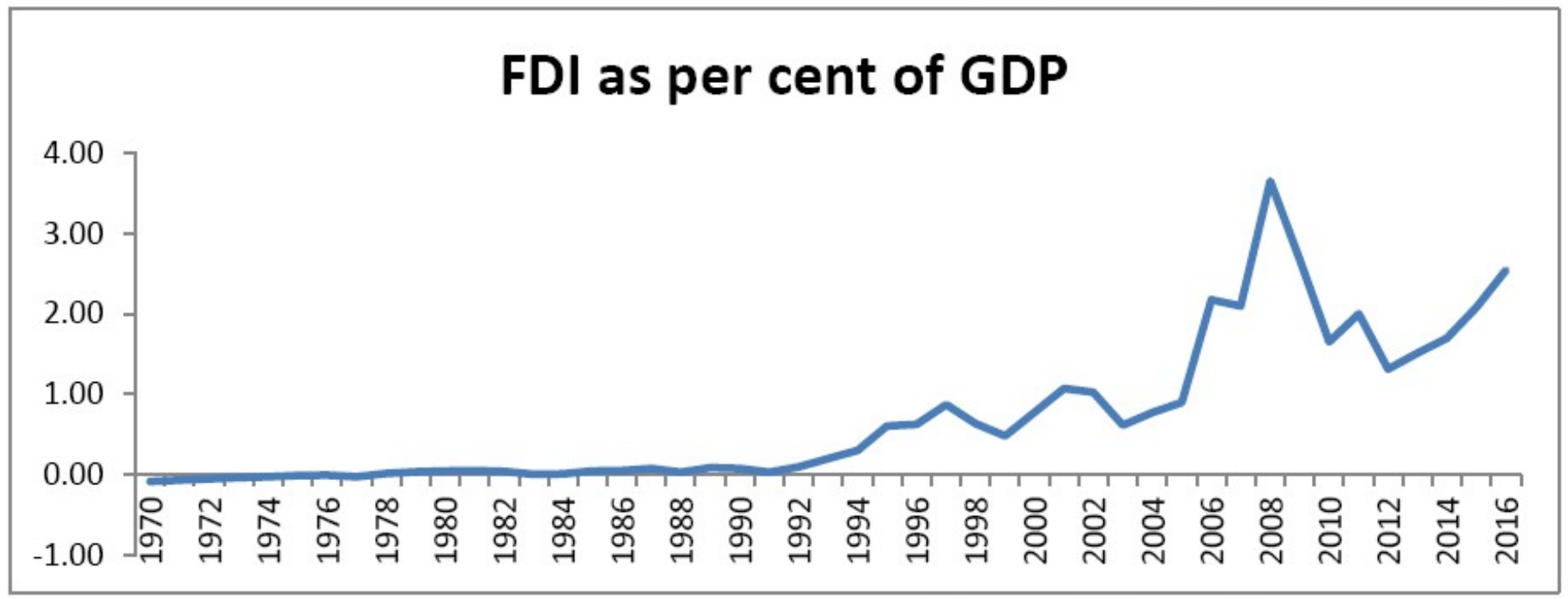

Author's Calculations

Source: World Development Indicators, World Bank Group

A correlation between FDI potential and FDI performance would be a useful analysis to comprehend and evaluate the FDI potential of India and its correlation with FDI performance.

\section{Table 5: Correlation between FDI}

\begin{tabular}{|l|l|l|}
\hline & FDI & $\begin{array}{l}\text { FDI } \\
\text { Potential } \\
\text { Index }\end{array}$ \\
\hline $\begin{array}{l}\text { FDI } \\
\text { Performance }\end{array}$ & 1 & \\
\hline $\begin{array}{l}\text { FDI Potential } \\
\text { Index }\end{array}$ & 0.860004 & 1 \\
\hline
\end{tabular}

The above correlation between FDI performance and FDI potential index is $86 \%$ which is highly significant. This clearly suggests that FDI potential is highly significantly correlated to FDI performance.

\section{RESULTS AND DISCUSSIONS}

The paper examined the FDI trends in India and concludes that in recent decade India has witnessed a substantial inflow of FDI mainly in services sector . The main reasons ogf this rise in FDI can be attributed to policy reforms instigated by government of India pertaining to removal of board in making the decision regarding the permission of foreign firms to invest in India and also empowering the various concerned ministries to take appropriate decisions related to FDI investment in India.

While evaluating various factors contributing in determining the FDI potential, human capital, infrastructure, $R \& D$ base and external trade are some 
of the significant variables determining the FDI potential in India. The appropriate indicators selected to explain each variable exhibits similar trends for the time period between 1990-2017. FDI potential index is computed using various appropriate variables using Principal Component Analysis (PCA). The index values show an increase in FDI potential in India between the time period 1990- 2017. After maintaining a constant level around 2008 to 2010 , the FDI potential again reflected a steep increase in potential in India. Further the variables determining FDI potential also move in the same direction as FDI potential Index.

A highly significant correlation value between FDI potential index and FDI performance reveals that these two variables are highly correlated, indicating the factors identified as variables affecting as well as determining FDI potential would finally affect the FDI performance in terms of FDI inflow as percentage of GDP. The study therefore recommends that is highly essential for government to implement appropriate policies related to human capital like health and education, the government must channelize resources towards infrastructure development and Research and development to foster FDI inflow in India. The external sector equally requires appropriate reforms to boost up external trade as trade is significant factor affecting FDI potential in case of India.

\section{BIBLIOGRAPHY}

1) Aksoy, F. G. (2016). Revisiting FDI-led growth hypothesis : the role of sector characteristics. Routledge, Taylor \& Francis Group , 1144-1166.

2) Alsan, M. a. (2006). The Effect of population Health on Foreign Direct Investment Inflows to Low and Middle Income Countries. World Development , 34(4) : 613 - 630 .

3) Bushan Yasmin, A. H. (2003). Analysis of factors affecting Foreign Direct Investment in Developing Countries. Jstor .

4) Dic Lo. Fuhai Hong, G. L. (2016). Assessing the role of inward foreign direct investment in Chinese economic developent 1990-2007 : Towards a synthesis of alternative views. Structural change and Economic Dynamics, 107120.
5) Easterlin, R. (1981). Why isn't the whole world developed? The Journal of Economic History, , 41(1): 1-17.

6) Findlay, R. (1978). Relative Backwardness, Direct Foreign Investment and the Transfer of Technology : A Simple Dynamic Model. The Quaterly Journal of Economics , 92(1) : 1-16.

7) Foreign Direct Investment (2017) , Indian Economy. India Brand Equity Foundation .Foreign Direct Investment, net inflows ( BoP, current US\$ ). data.worldbank.org.

8) Jr, L. R. (1990). Why doesn't Capital flow from rich to poor countries. The American economic Review , 80(2): 92-96.

9) Markusen, K. H. (1999). Vertical Multinationals and Host - Country Characteristics. Econppaers , 233-252

10) OECD (2002) "Foreign Direct Investment for Development: Maximizing Output, Minimizing Cost" What is Foreign Direct Investment (2012), Horizontal nd Vertical Knowledge Base. Guidewhois.com. 